\title{
"When I Try to Speak of What Is Buried in My Heart, It Feels Like My Heart Is Bursting”
}

Kang Il-chul

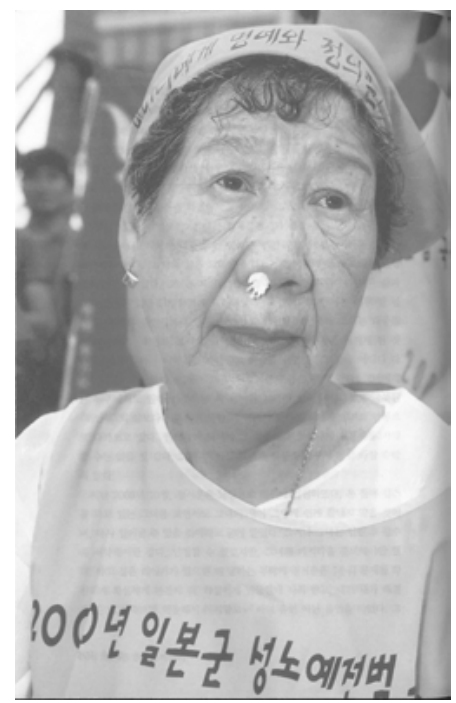

Kang Il-chul.

1928

Born in Gyeongsangbuk-do Sangju

1943 (Age 16)

Taken from her home and conscripted as a comfort girl-woman

Went to Mudanjiang comfort station via Andong, Sinuiju, and Changchun

1945 (Age 18) Rescued by Koreans in early summer

Took refuge in Elunchun

After the liberation, got married in Ji'an near Jilin City (first marriage)

1946 (Age 19)

Gave birth to a daughter who died shortly after

1949 (Age 22)

Worked as a nurse at a private hospital in Ji'an

1951 (Age 24)

Worked as a nurse at the second hospital in Jilin City

1955 (Age 28)

Got married (second marriage)

Gave birth to two sons and one daughter

1988 (Age 61) Visited Korea with the help of the Red Cross

1998 (Age 71)

Attempted to restore her nationality after visiting Korea

2000 (Age 73)

Permanent return to Korea

Recovered her citizenship

2004 (Age 77) Living at the House of Sharing in Gyeonggi-do Gwangju

Ә Open Access. ( 2020 Angella Son, published by De Gruyter. (cc) BY-NC-ND This work is licensed under a Creative Commons Attribution-NonCommercial-NoDerivatives 4.0 International License.

https://doi.org/10.1515/9783110670523-007 


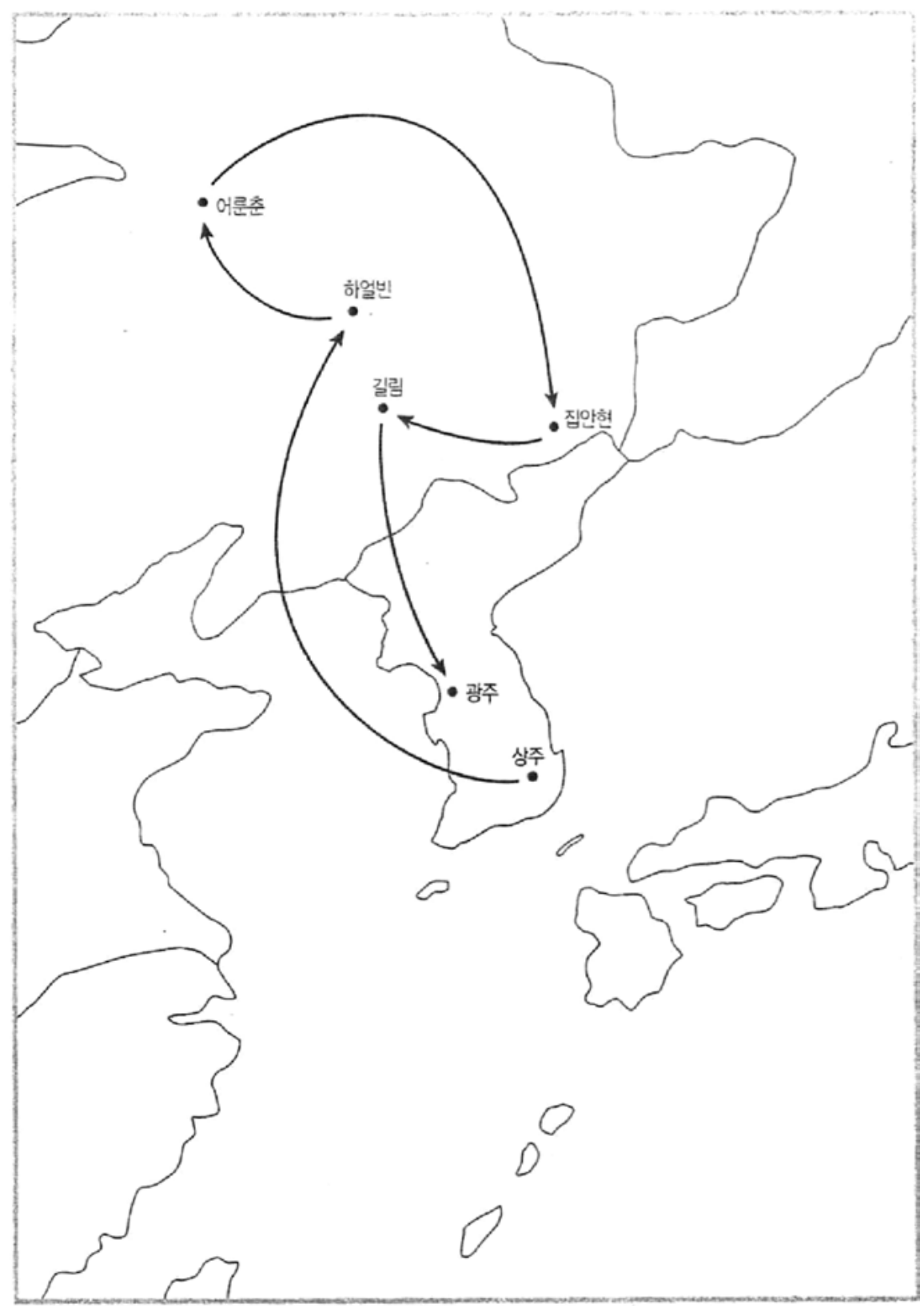

Kang Il-chul's route: Gyeongbuk Sangju - Elunchun - Ji'an - Jilin City - Gyeonggi-do Gwangju. 
"I am a member of a Full Gospel Church."

"I am not in China, but [God] is looking after all my grandchildren's education, so I can rest my mind a little easier."

"It is also because I am a widow: you know that God always pays a lot of attention to widows' children. Widows are not at all comfortable with receiving sympathy from others. Even though the wealthy bring a lot of money [to the church], widows do not get as much attention."

"I have gotten a lot of answers to my prayers."

"Even now, when I pray, I sometimes ask God for my parents to go to heaven as I would."

\section{The Youngest Daughter}

'Aheego- but you are a big baby. At your age, you are still piggyback riding on your sister.'

"My mother told me that I was the youngest out of twelve children."

"Even though I was the youngest out of twelve children, [my mother] said that she had a lot of affection for me, for me."

"My dad's beard is (making a shape of a beard with her hands) this long. While I was playing with my mom and dad, my mom would say to me, 'See how long a beard your dad has? Now you go and pull it.' Then, I would grab his beard and stretch it out."

"Then my dad would say that it hurt and fiercely chase me around. But he did not hit me. I have never been beaten by my mom or dad."

"When my older brothers came home after being out, my parents might not have brought anything back for their sons, but they surely would have brought back something for me."

"The school we went to was located across the mountains. There was a lot of snow at that time. At that time, it was not as hot as it is now, and snow came down like crazy, so I would grab the trees as I went up, and naturally, I would just slip and slide. So, my older sisters gave me a piggyback ride to school."

"When [my fellow primary school classmate] first saw me, he said, 'Aheegobut you are a big baby. At your age, you are still piggyback riding on your sister. You are such a big baby.",

"I learned Korean until the second grade, but after that, I was not allowed to speak Korean. I could not speak Korean. If I spoke in Korean, [the Japanese teacher] would slap me on my ear.” 
"I did not graduate."

"At grade four, I left without having graduated."

\section{A Policeman with a Sword}

I was so frightened that I was shaking like a scared dog, and I did not know what was going on.

"The head of a village had already spread the rumor."

"They did not say comfort girls-women, they called it public conscription. The public conscription of cheonyeo."

"At first, I went to another place and hid. I was at my mom's friend's house for a little while."

"Because I was the youngest, everyday, I was in the habit of sleeping next to my mother, in her embrace, touching her breast. So, I thought I could not stay in that house."

"When I was at their house, I thought of my mom and cried a lot, so they sent word to my mom. And so what could she say but tell me to come back. So, I came back."

"I came back to my home, but I could not even see my mom."

"The adults were not at home. Our house was situated a little away from the other houses."

"One Japanese man came, and one Korean man came."

"So, one with a sword (a policeman) came, and a man in yellow clothes (a soldier) came.”

"I was scared. Aheego-, whenever I saw a man with a sword, I would become so afraid that I would tremble like a leaf, and so I frantically hid at that time. I was so scared of policemen."

"They threw a piece of paper into the house before they left. ${ }^{1}$ When my nephew tried to stop them, they grabbed him hard and pushed him so that he fell backward. . . . Even when there were no adults in the house."

"So, it happened on the day I came home."

"My mom drove out one of my brothers. My [big] brother was not in the army, but there was another place to be conscripted into. She tried to send him there. My younger of the two older brothers was told to go to the army, but he

1 When the policeman and soldier took her, they threw a piece of paper with the name of Kang Il-chul written on it into the room. 
ran away to Japan, so he was okay. So, the two males had to go. Then, next, it was my turn to go."2

"At first, they did not tell me where we were going; it was the town's leader who said that we would go to a place where we would weave, a place where we would weave cloth. ... We had no idea what they did there. Because we were too young then, very young in years."

"I was sixteen. I left when I was sixteen years old."

"I had to get a ride in Sangju. Even then, it was Sangju City."

"They loaded us up on the car where you would normally put your baggage and such."

"Some of the girls were sick or something, so they just lay down. They may have been ill or frightened; I did not know."

"And then we went to Gimcheon and got on the train."

"We were loaded into a place without seats where they loaded up the luggage. We were taken back only after we had run away. After we had hidden somewhere. So-, we were treated badly. Even when I tried to see the outside, they made it difficult for me to do that."

"I was given some things like rice balls and Japanese radish. Those were all I got, and they did not go down easy."

"I was so frightened that I was shaking like a scared dog, and I did not know what was going on. We did not even know that we were hungry, and all we did was look at each other and cry. Wondering where we were headed."

"To North Korea to Sinuiju to Andong, yes. We did not know where we had gone to. I do not know how or why, but with my mind frantic, I looked out for a little bit, and I saw a lot of Chinese people, not our Korean people, and they were all speaking Chinese."

\section{Changchun}

I did not do much except, what was it, I did the laundry for them.

"At first, we were traveling, then we stopped at Changchun and stayed there for a little while. We were there for more than twenty days."

"At the time, including me, there were six people."

"Inside, the armies stood like this. They were standing on both sides of me. So, how could one as small as me who could not even speak the language get

2 Kang Il-chul thinks that she was taken away because her brothers were not at home. 
out? If only I knew the language, maybe. Or if I had been there for a long time, I would have done something to be able to leave. ${ }^{3}$ We were scared to death, and just looking at them in the face was enough to make me faint. So, I had no choice but to live like that."

"For our meals, what was it, they gave us corn cake. That is what they gave us. It was our first time eating it and we did not like it much. With white rice, with rice, if you make rice cake, it sure tastes good. So, it did not feel as though we ate anything. They would only give us soup without much in it and tasteless corn cake. Otherwise, they made rice with sorghum. Sorghum is not sticky, especially Chinese sorghum. It is the kind that is not sticky and you cannot make rice cakes out of it."

"What did I [do] there? I did the laundry for them. For the soldiers. I did laundry with the people who remained."

"Things like military uniforms and socks, things like that. I only hung out the laundry. [Doing laundry] is work for middle-aged women. There were about ten [middle-aged women].”

\section{The Life of a Comfort Girl-Woman}

I was all torn and hurt. I guess it was because it was torn that I hurt.

"After the twenty days, next we went to Harbin and then to Mudanjiang (Mudan River).”

"When we arrived there, it was August; in September, well, it snowed there."

"At that time, I was not very tall, since I went there when I was a student. I looked after three of them, you know, those people who cannot see. ${ }^{4}$ I took care of three people, but then another person came. So, that made it four. It was very difficult to look after them all. By myself. So, they sent another woman. And the two of us were looking after them, but one [blind man] left a little earlier than the rest. . . . So, since there were now three again, they made me take care of them by myself."

3 She stayed with the army in Changchun for about ten to twenty days, and the women who had been doing the laundry for a long time were able to go in and out of the building within the comfort station.

4 Kang Il-chul arrived at the Mudanjiang comfort station and nursed Japanese soldiers who had lost their sight before she lived as a comfort girl-woman. 
"So I had to do everything: I had to prepare the meals and take them to the bathroom, everything. That is, I had to put their clothes on too, and I also had to feed meals to those who were really having a hard time eating by themselves."

"After sending [blind patients] to Japan, I was assigned to work as a comfort girl-woman.”

"It was after the liberation that I got my period. So I did not know about it [before that] because I did not have it. I was just like a man. I was clueless. At that time, I was young, and not so bright."

"Then I became an adult. I was not even an adult yet, so what did I know? I knew nothing. So, that is why I feel the injustice of it more."

"Since the [penis] did not go in and something wrong happened down there, it hurt so."

"I was all torn and hurt. I guess it was because it was torn that I hurt."

"So, I was given a shot because they were afraid that I would contract an [STD]. . . . It was shot \#606."

"And they also gave you something to wash with beforehand. If you did not clean yourself with the medical solution, it would be infected and rot, which would be hard to cure."

"The color [of the medicine] was purplish - a reddish-purple color."

"I was young and the soldiers would leave almost immediately, so people of higher rank came to me."

"They do not go to a woman who has been around a while for fear of contracting a disease, that is, the high-ranking officers. . . . If you contract an illness like that, it is very hard to fix."

"The women who had been around a long time, the head honchos did not go to them. It is like how all men want to marry a virgin; they do not want to marry women who had been married before. They say that marrying a virgin is better, even if it is for the second or the third time, right? For people with money, this one thing is easy to get. If you are of a high rank, you can do whatever you want."

"Even with your own man whom you live with, sometimes you do not feel like having sex. That is the hardest, the hardest."

"I was hit here (on the top of the head), and for a very long time, I had no hair here. I still have nosebleeds. So . . I I thought I was just going to die. My face would go as white as a sheet."

"The room was this small. And they pushed me down in that small place."

"What reason did they have? If you did not do what they told you to do, they hit you like that."

"Uh-, I was bleeding from here, and it became all swollen. My face was all swollen too." 
"If I tried to go to the hospital for treatment, that man [the high-ranking officer] would come down. Because he was a minister. (Pointing to the shoulder) It was a man who had stars here. He was a man who had three stars. Since I was hit by him, the man would fall in rank."

"So, they did not take me to a big hospital and made a nurse and a doctor come instead."

"The soldiers also had to bring tickets to be entertained. If they did not bring tickets, they were not received. That is how it was. Only if they had bought tickets there could they come in. They sold them at the place where the army was. Even a person who stood in line could not enter the rooms without a ticket."

"They did not come that much. The most that came was . . . about eight old people a day."

"As for money, it was the ethnic Koreans living in China who would give you a little. ... Out of the Japanese people, the one who hit me gave me some money."

"There were ten-won ${ }^{5}$ coins. . . . And there were five-jeon ${ }^{6}$ coins, coins with a hole (simulating the shape of a coin by hand) like this."

"At that time, ten won was big money."

"And sometimes they would bring me some tasty things to eat."

"No one could spend [the money]. We could not go anywhere."

"Barbed wire was set out all around. And since I was young and had not been there for very long, they never let me out. The old women went out with the Japanese people including the generals, but we could not even think about going out."

\section{Mr. Kim}

Maybe I will meet him again someday. I think in my gut that I will meet him again.

"And I had typhoid fever."

"Because I was sick from the illness, and because my head was hurt, I had a lot of fever. And since I was running a very high fever, I kept wanting to drink water. . . . I closed my eyes but could not clear my head. I was so out of it, and

5 Ten won in 1943-1945 is worth approximately $\$ 61.00$ today.

6 Five jeon in 1943-1945 is worth approximately $\$ 0.30$ today. One won is 100 jeon. 
when I could focus my mind a little bit, I felt like I would die of thirst. As soon as I drank some water, I felt a lot better."

"Because it was typhoid fever, the fever was rising. It was an epidemic. In the olden times in Korea, if the disease passed through, everyone in the neighborhood would die. They would all die. That was the kind of sickness it was."

"I had a high fever. So, people called it a head-aching disease. There were several people, maybe about eight people, some lying down in the car, some sitting down. They were taken to be burned."

"To burn them. To burn them in a fire."

"So, they dug a hole, put the firewood in it, and doused it with gasoline; then, it just burned. They just threw people in there. ... They threw me in there, but I was thrown in there last, so I was on top."7

"Four people went [to burn the sick people]: one Korean man and [three Japanese people]."

"Only the two people on top survived."

"There was a Korean man among the soldiers."8

"The man in the comfort station was Mr. Kim. He was the person who was contacting the Korean Independence Army."

"He said to me that we will be liberated soon, no matter what these bastards (the Japanese soldiers) are doing now."

"And then, Mr. Kim beat up and killed two Japanese people. Beat up and killed them, he did, but I do not know whether one of them lived or died. . . . He kicked him hard, but I do not know if he was dead or alive. Who cares. I saw him fall. He was shooting off a gun. But we do not know, because we were in pain all over and had a fever of forty degrees."

"So, Mr. Kim contacted [the other soldiers of the Korean Independence Army]. [The Korean soldiers that were contacted] carried us on their backs and put us in a cave in the mountains. They said blood squirted out of my head like a bullet might be fired from a gun."

"When I asked after I was better, what was it that they said? They said that [Mr. Kim] went to Baekdu Mountain. Baekdu Mountain is [known as] Changbai Mountain in Chinese."

7 At the time in 1945, typhoid fever broke out in the Mudanjiang comfort station, and the Japanese transported infected people to the mountains on trucks to burn them. Kang Il-chul said she was able to survive because she was the last one to be thrown onto the firewood.

8 Kang Il-chul remembers that there was a Korean, Kim, in the comfort station, who was a soldier of the Korean Independence Army, disguised as an officer of the comfort station, and who hid the fact that he was a soldier of the Korean Independence Army. 
"[The soldiers of the Korean Independence Army who took care of me] said to me that he went to Changbai Mountain and would come back in a few days."

"That man said that when we were liberated, he would come to our house, to Sangju where we lived, and live there too. The man thought a lot- about me."

"[Mr. Kim] told me that he would seek retribution from these bastards someday. He said he would seek revenge, but I did not know [then] what kind of revenge he was talking about. I know now."

"The man, he went to Changbai Mountain, and then I was not able to meet with him again. You never know. Maybe I will meet him again someday. I think in my gut that I will meet him again.”

"Those bastards (the Japanese soldiers) were something else. But [the Korean Independence Army] killed the Japs. So, we went to the border [to avoid the Japanese soldiers]. The place was called Elunchun."9

"I was wandering around with no shoes on my feet. I peeled the bark off the trees and made clothes to wear. That is how I made most of the journey. There was a secluded place near the mountain where, when I looked around, there were fish jumping in and out of the water. So, the men (the soldiers of the Korean Independence Army) caught the fish and brought them back."

"So, I became a little better, oh, what was that, and I transported some things a little bit."

"I took a note with me, I did, [and] hid it. I brought it to a remote house where a father and a child lived, and when I brought it to the house, they would take it from there to another place. In this way, we used to send [messages] for three or four months."

"Let me explain how we would do it: you know those burlap sacks. And in there would be a big hoe or a pickaxe. With a bent blade like this, like this. We would put it inside there."

"When I went to that house, they would catch a chicken and we would eat it. We would put some roots used for medicine in the sack to make it look like a sack for medicinal roots."

"I would wear a towel like this and go with a man as if we were gathering medicinal herbs, and we would come and go as we pleased."

"After three months of that, the news came to us that we had been liberated. Then those (the Korean Independence Army) who were in northern region were searched out so that they could come back to Korea. I do not know if they found them or not. . . . There were a lot of Koreans when we came out to the Jilin. So, I stopped there for a little while, and then I went to Ji'an where, if I crossed the

9 Elunchun is located in the forest near northeastern Heilongjiang in northeastern China. 
river, I would be in North Korea. . . . Even so, I could not live there for long, and I ended up going back to the Chilgu in Ji'an area. That is how it turned out.”

\section{First Husband}

He said that when the roads opened up, he would go with me to my hometown and live with me there. He was very good at heart.

"At that time, there were no bags, no nothing. I packed up a few of these (pointing to clothes around the place) in a wrapping cloth and brought them with me, and I did not have [much] money either. Anyhow, there was no place to put the money. I was wearing a skirt, and so I took what little money I had. . . . I wrapped it in a piece of cloth . . . and used that like a pillow when I went to sleep. I do not know when they took it, but when I got up, everything I had wrapped up in my wrapping cloth - like my clothes and everything else - was gone. The money too, there was not a coin left. So, the man who came with me sold me again. Again.”

"[I was sold] to someone from the Roh family. The grandma of the house was a North Korean woman. Even though they were North Koreans, in this family, everyone had gone to China since the time of their grandma, and either did not know any of their relatives at home or did not have any at all. Still, they were all North Koreans. The family bought me with money. . . . During the three years of farming I did for the family, I ate the food that they let me have."

"There was a son in the family. During the time of the Japanese occupation, he was a junior high school student. At a Japanese school."

"The man was tall and was very handsome. So, I had a soft spot in my heart for him, and he was a very good man. He said that when the roads opened up, he would go with me to my hometown and live with me there. He was very good at heart."

"I married into the family."10

"My husband treated me well. If [my mother-in-law] were mean to me, he would hate it, and there would be a fight between my mother-in-law and my husband. Yes, they sure did."

"I was cooking some rice, and the rice was boiling, and so I could not leave when I was called. While [my father-in-law] was drinking, he opened the door and said, 'Bring your omani. ${ }^{11}$ ' He called [my mother-in-law] omani. That man

10 Kang Il-chul did farm work at Roh's house and married Roh's eldest son.

11 Mother or mother-in-law in the Pyeongan-do dialect. 
of Pyeongan-do. He said, 'Why aren't you bringing your omani? Why aren't you?' What was it, he took the military boot of the Japanese army, raised it over me - me, who was only fanning the fire to cook the rice in the corner - and hit [me with the boot] for not going, at which time, this tooth broke off. So, my mouth (sticking her lips out) became like this. Then, my husband came. After returning home and seeing me, he asked, 'Why is your tooth in that sorry state?' So, I said it was because I did not go fast enough to fetch his mother when I was told to. The rice was boiling, and I had to do something to the fire before I left it or else how could I go? I told him that it was because I did not go and bring [his mother] that he did this. When I said this to him, [my husband] frantically said, 'Hurry, go. Go to my eldest uncle's house. Go to his house and stay there.' His eldest uncle's house was nearby. He told me to go. Because he kept telling me to go, I went, even before preparing the rice and setting the table. Then, his mom (my mother-in-law) came carrying one of her sons on her back (at that time she was in her thirties). When she came carrying her baby on her back, because she was still young, my husband said, 'Look at that. Look at what he did to her with the boot. What are people in the neighborhood going to say? If you are going to be a parent, you have to be a good parent. She does not have even relatives or anything here.' When he attacked his father by saying that this family would fare better if [his father] treated me better than his own children, and demanded to know why he had done this, his mother said, 'Hey, you, son-of-a-bitch.' In Pyeongan-do, they often use the term son-of-a-bitch. She said, 'Hey, you, son-of-a-bitch. How can you say that to a drunken man? You are still wet behind the ears. You are too young to talk back to your father like that, even if it is to defend your wife."”

"Even before fall came along, my husband went to the army in July. There was no choice; he had to go. It was because there was a big fight between the National Party and the Communists." ${ }^{\prime 2}$

"After the liberation, there was a fight between the Communist Party in China and Taiwan. That is when he went out there and died."

"At that time, my child (a child born to my first husband and me) was taken ill. She would not have died from pneumonia if she could have had just one or three to four injections. She had measles, which developed into pneumonia.”

"So, she died. Even though my baby was sick, they did not let me take her to the hospital, and they did not give me any money. So, my baby ... even when she was about to die, I could not buy her a lousy scoop of ice cream because I had no money. I could not even tell whether my child- was dying or not

12 The part of the Chinese Civil War that took place from 1946 to 1949. 
because I myself was so young. [My mother-in-law's] parents lived in the same neighborhood, and she went to them and did not come back even when it became dark out. I did not make the rice. How could I? My child was sick."

"She ground her teeth furiously. My child did. Then she slowly closed her eyes. After she was dead, I covered her with a quilt like this. The mother-in-law came in carrying her child on her back and asked me, 'How is the child?' I was still and did not say a word. The father-in-law also came in with her.”

\section{A Nurse}

I went to a big Chinese hospital and worked at a place where they treated people's eyes.

"The head of the village said to me, 'If you stay in this household, it might just kill you. All you do is work, and in the summer, you walk around barefoot because you have no shoes.' I suffered a lot living like this.”

"What can I say here. Uh- in a remote village . . . the village leader said, 'I will introduce you to a place. It is a small hospital where my relative works in Jilin City."

"I went there and did my work. I did it. I gave shots too. It was my first time giving shots, but I had no problems. This was because I saw him (the doctor who treated the blind people at the Mudanjiang comfort station) doing it."

"I was in a private hospital for a while, learning how to treat patients, and then I went to a big hospital because there were not enough people there.”

"I went to a big Chinese hospital and worked at a place where they treated people's eyes. I worked at the eye clinic and then went to the dental center. It was a big hospital, but it was a hospital that was established together with a dental center. Our hospital was the second-best hospital in Jilin City, China."

"When the doctors did not come, I looked at the patients. There was one chief person in charge of the ophthalmology department, where they treat eyes, one chief in charge of the ear department and one chief in charge of dentistry; there was one person in charge of each department. The chief who had come to our dental department could not pull out teeth and could not administer treatments. But because I was a quick visual learner, I could do all the pulling and knew what medicines to apply where."

"While people who had just graduated were working with me for a year, a person had to pull out a tooth, but instead of pulling out the tooth that was hurting, he pulled out one that was not hurting. But, the chief could not take care of this matter, so without him knowing, I took care of it." 
"I told the patient, 'Please bear with me. This person is a young man and a person with a future. If you do a good turn, a good turn will come to your kids.' So, he turned a blind eye but did not pay. I asked him to think of it as doing me a favor. He thought I was amazing, that doctor."

"I was a head nurse, so I was higher up than regular nurses. In rank. There was a doctor of internal medicine and a departmental head, and I received more money than them, I did. It is a college student who becomes the head of the department of internal medicine. Above him, there were a director and a chief. And there were also head nurses in the hospital rooms. There was more than one head nurse. There were several."

"If you were better at doing things, for example, giving these shots better than others, then you became a head nurse. There had to be a little bit of this ability. But, you have to be more than just good at your work. If you could not speak well or if you were a little awkward, you could not make it."

"I went to work, carrying one baby on my back and holding the hands of the two kids, ${ }^{13}$ slipping on the sheets of ice and falling over. It was very far away. It was hard for three or four people to climb into the car (public transportation) together. The car was tiny. When the car came, some men just pushed up their heads to make an opening and went up."

"So, I was more distressed than anyone else. I had to arrive at 5 o'clock in the morning when others could arrive there at 5:30 a.m."

"If I went to the mountain to get medicinal herbs, I had a hard time since I had a son whom I had to feed regularly. Because I had to feed my baby, I brought the baby on my back. And when I brought my baby, they (the nurses who worked together with me) took care of the baby, and I looked for the medicinal herbs."

"My daughter entered the hospital where I was working instead of me."

"[My daughter] must have been about nineteen."14

"Because the officers said that [children] could not replace their parents, I left the hospital saying I was seriously sick to help my daughter so that she could work in my position at the hospital. If not, I would have had to work three or four more years."

"I had no choice but to leave my job for my child. If I did not, my daughter would not have had a job, and I did not want her to meet a bad person while working here and there. So, I gave up my position at work."

13 Kang Il-chul remarried, while she was a nurse, and gave birth to one girl and two boys.

14 It is estimated that Kang Il-chul worked in the hospital from 1949 to 1980, when her daughter turned nineteen. She intentionally left work to let her daughter replace her in her position. 
"If I had not done so, I would have made a lot of money because I had a long service record."

\section{Betrayal}

I cannot forgive his betraying me like that.

"When I was at the hospital, what was it, the woman at the drugstore introduced me."

"[My second husband was] a Korean man. He also grew up in someone else's house because he had no mother and father."

“My baby's father was very- handsome. Haven't you ever seen the face of Kim Il Sung? He had more teeth than Kim Il Sung, and when he smiled widely, everyone said he looked so cool. Everyone who saw him said he was handsome. Still, there was a price to pay for his looks."

"A crazy bitch and a crazy bastard, that is what my second husband and the woman he had an affair with were like."

"Even though he earned money, he did not bring it home to me; he and other women would spend it eating and carousing around together. I was very hurt by that."

"All he wanted to do was drink, and the only people that he liked were his friends. Even if he were to leave me, I would rather that he met someone better than me. But she was short and had a dark complexion. That is the kind of woman he got to run around with."

"'I would be okay with you seeing another woman; it would be okay as long as you brought home the money. You can just go and live there. I have three children, and I have to see them through their studies. So, just go-.' Even though I said this, he did not go, and he went there to sleep and came home only at around five or six in the morning."

"Right after I had a wedding ceremony, I had a baby, and after a year and a half later I was pregnant again with the child's younger sibling, a boy. And that woman's [baby] was the same age as my second child. If I gave birth to my child in July, she gave birth in the 11th month of the lunar calendar. He saw the birth of two sons that year, that man did. So, just imagine how I must have felt."

"Even so, I thought maybe he would mend his ways once he saw his son, but he did not mend his ways. So, at last, I got divorced. He asked for it, so I gave it to him."

"I just do not want to see him, not even in a dream. I cannot forgive his betraying me like that." 
"I overcame what the man did to me. Also, at first, I overcame what my parents-in-law did and found a way to live. So, I think I felt the most comfortable when I was by myself.”

\section{Return}

I came here, and when I went back to China, I carried the soil with me. I would always travel carrying Korean soil with me. I did.

"During the holidays, especially during the Korean Thanksgiving season in August and on New Year's Day of the lunar calendar, I shed many tears when my children are not looking. Well, I cannot very well shed my tears when my sons are looking, can I? But the tears certainly always come during the holidays. And since I was the youngest of twelve, they raised me soft and gentle like. At that time, silk merchants used to come. Then [my parents] bought me a traditional Korean yellow jacket with a bright red border and a new traditional Korean skirt, and they would buy me another set on New Year's Day. And my mother would carry me on her back. I remembered it because I had become mature enough to. My older sisters and brothers all sewed in the bright moonlight. ... When the moon is full, it is very round. Then when I thought about that, even when I was alone, I cried many tears.”

"In 1988, I came back once. At that time, I came by way of Hong Kong. I could not come [directly] here [to Korea]. I was asked to come by the Red Cross. ${ }^{15}$ I had my family register, you know."

"Like the other separated families, I was motivated and able to come here due to the efforts of the Red Cross."

"A place called Guangzhou in China and a place called Sunjun are the places where I come from. ${ }^{16}$ They are situated across from Hong Kong, right? I came back here in a roundabout way via Hong Kong then too. . . . My nephew lives in Seoul. My nephew came out to meet me.”

15 Prior to diplomatic relations being established with China in 1992, travel liberalization did not take place, and there were restrictions on visiting South Korea. Kang Il-chul visited South Korea in 1988, at the request of her nephews, as part of the Overseas Koreans' Home Visit Project undertaken by the South Korean Red Cross.

16 Guangzhou and Shenzhen are located on the border of Hong Kong and belong to the administrative district of Guangdong Province. 
"When I came then, since my brother was gone, and my parents had both passed away, I cried so much that people said that this was the first time they had seen anybody cry like that at the airport."

"What more is there? I came back, but people told me to go to China because I was a Chinese person. . . . When I think about that, my heart aches so much-."17

"I came here, and when I went back to China, I carried the soil with me. I would always travel carrying Korean soil with me. I did.”

"In about the year 1998, I came and then I went back. I could make my living in China. And when I went back to China, I was in the newspapers.”

"I did not do it; it was a school friend of mine. My friend was in the same class as me." 18

"She said that it would be good to let people know since I had come such a long way and all. 'Now that we are all old, it is okay to tell, and you will not end up getting married anymore,' she said."

"When I told the broadcasting station that I was taken as a comfort girlwoman, someone came from a newspaper. A person came out to see me, and then I was in the papers here."

"I had to be able to guarantee thirty million won ${ }^{19}$ in land or money for me to get on the family register."

"When I asked my nephew to do this for me, he found out that my younger brother's family would do it for me, but the eldest brother's family said no.”

"My nephew said, "Aunt, I will do this for you. Do not worry. Another nephew and I will take care of it together."”

"My tears poured down like sheets of rain. This was because if my [big] brother had earned money himself and bought the land, I could not say a thing. I am not such a thick-skinned person as all that; it is just the circumstances I was in. Everything was paid for by my parents who earned their money by working until they sweated blood. When my mother came into the Kangs' house, she did not even have a dish to call her own and had to eat her meals in a bowl made out of a gourd. So, when they acted like this, maybe it was because I thought of my mom, I cried, I cried like a baby."

17 Kang Il-chul did not recover her nationality when she visited South Korea in 1988, so she only stayed in South Korea for three months, which is the legal limit for foreign visitors.

18 During Kang Il-chul's visit to South Korea in 1998, she met an elementary school friend. Her friend informed the media about her, and her wish to recover her nationality was reported in the Chosun Ilbo ("Testimony of a resident of China, Kim Mal-sun halmoni's past life as a comfort girl-woman,” Chosun Ilbo, April 9, 1990).

19 Thirty million won in 1998 is worth approximately $\$ 41,291.00$ today. 


\section{Resentment}

But, I do not know why the Korean government is acting like this, like this, uh-.

"You cannot attach the military prefix. If you say military comfort girls-women, that is wrong, that is. You have to say comfort girls-women. Military comfort girlswomen volunteered to go on their own. These people went in to make money. We were forcibly dragged away, that was it. . . . The women who were dragged there by force, they are comfort girls-women. So, you cannot say like that."20

"If I die after having used all my power to correct this problem while we are all still alive, then I would die happy. . . . But I have to think about our country. We really suffered, and as one who almost fell into the fire pit but came back, I cannot ever let this happen to my descendants."

"I do not know how to speak well, but I can say what I have [experienced] first-hand in one or two words. So, it is okay for me if I do not have my own house, but why would I again let some foreigners take away our country where our parents and ancestors are buried? In a word, that is why I am here. . . . No matter what I have to do, I will plant seeds with even one word of mine to stop the Japs and the foreign bastards from ever invading our country again. That is why I came back here from China. I mean, really."

"It is our future generations that must forever guard the country of Korea. If just one word of mine can leave a lasting impression on just one person, I would really thank God for it. If there is just- one person who would protect our country, then it is better. I really want to see my children. When they call me on the phone, I become so- worried and anxious that I cannot go to sleep. But that is just my little household, and without a country, there is no me. If there is no country, what joy is there in being born into the world?"

"I am thinking of going to China next month. ${ }^{21}$... Until now, for the first time. Now, for the first time, I am leaving."

"I am not nervous. I am just going to my home, to my house. It is not my son's house but my house."

"I have earned a lot of brownie points. I worked for thirty-two years, you know. So, I was awarded a house, I was. . . . It is in a very good location in Jilin City. . . . The biggest road in Jilin City is in front of my house. . . . It is the Liberation Road."

20 Kang Il-chul seems to distinguish between girls who were forcibly taken like herself and others who voluntarily joined to earn money. She does this by adding the word 'military' to denote those who voluntarily signed up to go to comfort stations during the war.

21 Kang Il-chul went to China in December 2002 and stayed there for about two months. 
"But, it would be nice if my son and daughter were to live near where I live."

"If they could just be with me while I am still alive, I could close my eyes in peace when I die. . . . For me, the fact that, throughout my whole life, I could not live with my blood relatives before they died is one of my biggest sorrows. My daughter also has some money. And as for my eldest son, if I were to add a little bit more to what he can scrounge up for himself, he would not have to go to the government for welfare benefits."

"I have left my sons and daughter, and I am here for this government. But, I do not know why the Korean government is acting like this, like this, uh-."

"So, what should I do? What should I say to the National Assembly's Women's Department?"

\section{Interviewer's Commentary: 'For the Country’ of Kang Il-chul}

Oh Yeonju

In June 2002, the first meeting with Kang Il-chul halmoni started with a pleasant picnic. The Anmyeondo Island excursion, which was provided by the Korean Council as a part of the welfare program for the victims, was a chatty and leisurely excursion, unlike the heavy feeling that the word 'victim' evokes. The halmonis poured out songs, jokes, and past experiences all at once, each in their own personal color. Without a moment's rest, Kang Il-chul halmoni too unknotted the yarn of her story: from her memories of her childhood to the sorrow of her return home to Korea, her current life at the House of Sharing, and even the experience of violence inside the comfort station. The two-day trip seemed to give more meaning to the halmonis than a mere picnic. Their lives were different, but the halmonis had the common experience of being a comfort girl-woman of the Japanese military. And the halmonis' picnic was a place where they could shed the careful routines that they had to hide from their children, relatives, and neighbors that they were comfort girls-women and relieve their anxiety, even if it was just for a short time. Thanks to this, the halmonis broached many stories without having to close doors or having to look around to see if anyone was there, and Kang Il-chul halmoni also unfolded her past experiences. This active attitude of Kang halmoni relieved me of my worries that she would not accept to do the interview, or that she might remain silent throughout many parts of it even if she were to agree to do it. It was quite a good experience to have a picnic with the halmonis in the process of getting to know each other before the interview.

After the picnic, I met Kang halmoni two or three times during the Wednesday rallies. In July of 2002, I sought out the House of Sharing in Gwangju, Gyeonggi-do 
to request an official interview. The halmoni's relatives live in her old hometown of Sangju, Gyeongbuk and in Seoul, but she has been living at the House of Sharing since she permanently returned to Korea from China in 2000. This is because she thinks it is unnecessary to obtain medical-related or financial help from her relatives yet. The House of Sharing was well-equipped so that it would not be inconvenient for the halmonis to live there, but she often complained. Her biggest complaint is about religion: this is because while she is a devout Christian, the House of Sharing is operated by Buddhists. Kang halmoni said, "I am fighting hard with myself [to keep my faith in God]," maintaining that "God sent me here to overcome this." And these words of hers were also expressed in small quarrels with the family members of the House of Sharing. Kang halmoni told me that she does not feel at ease because she has a different religion, but she goes to a church nearby every Sunday morning without fail.

Upon my request for an interview that I carefully broached after I had looked around the House of Sharing, Kang halmoni decisively refused. It was the moment when the trust in the friendship built on the encounters at the picnic and Wednesday demonstrations collapsed. Throughout the picnic, she had insisted on taking pictures with me, saying "I will introduce you to my

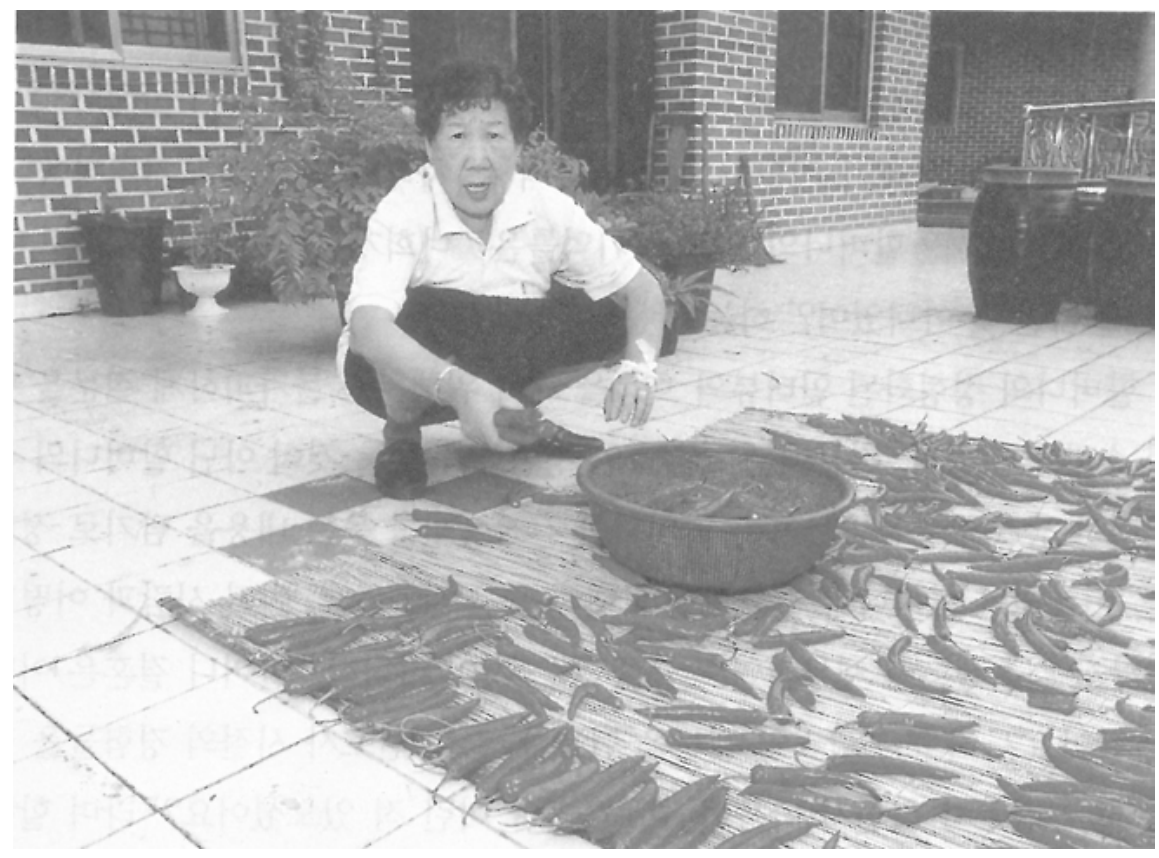

Kang II-chul. 
nephew's son in my hometown," and when I first visited the House of Sharing, she introduced me to others, saying "This child is a close friend of mine," but this friendship did not result in accepting the interview. Rather, the friendship that we had built before the interview became a stumbling block. The student, whom she was only thinking of as her nephew's potential daughter-in-law, was asking for an interview all of a sudden, and she might have felt embarrassed. But even after I was denied the interview, I kept asking for a month through phone calls and the encounters at the Wednesday rallies, and Kang halmoni finally revealed the 'history' she did not want to recount, saying, "So what are the stories do you want to hear from me?"

Kang halmoni's story was relatively accurate in terms of space and time as if she were slowly reading down a list of well-organized notes. The contents of her testimony (edited) that connect her stories of her childhood, the circumstances of her being drafted as a comfort girl-woman, Changchun, Mudanjiang, Ji'an, her life as a nurse, and returning home to South Korea are in the same order as she said, and the range of that memory was also intact. In comparison to her 1998 interview with the Institute, which I read before I visited the halmoni during the interview preparation process, I found her story mostly consistent, and her memory relatively accurate, without a large part having been lost or a large part being added. She repeated a similar pattern during four interviews, so it was less burdensome for me to organize the tangled memories. However, on the other hand, I was concerned about how to be free from her formulaic memory and, more than that, about why her memory was cemented in that way.

The above-mentioned interview with the Institute was done before Kang halmoni returned home permanently. In other words, for a halmoni who had never revealed that she was a comfort girl-woman while she had been living in China, the above interview was done with little oral experience. Therefore, did Kang halmoni design the frame of her memory before the interview with me? During her four interviews, she told me that nobody knew how to recount 'history' as well as she. The 'history' that she was talking about was only the life of a comfort girl-woman that has come to take up more than half of her life, and she seemed to think that it was the only thing an interviewer wanted to hear. Therefore, has Kang halmoni's memory perhaps been formalized through previous interview experiences? It was not whether she had summarized the important parts of her life herself, but rather whether it had been edited after several interviews. Her fixed frame of her memories was like a question that kept coming back at me: 'Is this not what you wanted to hear?'

Inevitably, I had to ask questions to break the flow of Kang halmoni's formal interviews. I decided not to ask about factual experiences, but to ask about her overall thinking or her emotional state. For example, when asking about 
her marital life, I did not ask about the details of when and how she met and married a certain person, but instead threw her a comprehensive question: "What do you think about your marriage?" Or, when asking about her nursing experience, I asked her questions about her feelings at that time, like "Have you ever felt proud as a nurse?" She brought up a story about her second husband's extramarital affair, saying that we must marry, but we should avoid "a man with a good looking face." When she talked about her nursing life, she said that she saved a lot of people, but that she also missed her first child whom she could not save. She declared, "My daughter died. I had no money. I had nothing. She died because she could not receive treatment."

She filled up quite a lot of her interview time with complaints about her present life. These were her major complaints: the apology and compensation problems of the Japanese government show no sign of being resolved. Conflicts were arising from living with other halmonis in the House of Sharing. The National Assembly and the Ministry of Gender Equality seem to be indifferent to the welfare of the victimized halmonis and the resolution of the comfort girls-women's problems. Kang halmoni had only one personal request: to be given a house where she could live with her son and daughter and their spouses living in China and her youngest son, who lives far away in South Korea. When the same complaints and demands were repeated in the halmoni's stories, I would ask appropriate questions to change the subject. However, the halmoni continued to rant regardless of the question and endlessly poured out these requests and complaints into the dictaphone, as if she thought that, as well as me sitting right in front of her, someone from the Korean Council or the Ministry of Gender Equality would be listening.

Kang halmoni's complaints and demands were not disparate. She wanted the government to show more interest so that she would be able to receive compensation more quickly, and for her, compensations means that she could prepare a house where she could live with her children. Exposing the conflicts that arise at the House of Sharing, she also told me that she would leave if she could only have a house to live in, but this house must be big enough for her to live with her children, not a place where she could live just by herself. In the summer of 2002, she found a rental apartment that was not cramped for one person to live in, but she did not sign the contract, saying that the house was not roomy enough. Her current discontent and troubles have become a kind of precondition for certain demands.

Throughout the interview, she often pulled out phrases like "for my country" and "for my posterity." She thought that revealing that she was once a comfort girl-woman and talking about her experience were in the national interest. Accordingly, she called her story 'history' and stressed the value it had. And by telling that 'history,' she said that if the next generation correctly understand the facts about the past, no material reward is necessary. However, 
when she complained about her inability to live with her children, she expressed her disappointment and asked why she had been given no material reward even though she had abandoned her comfortable life in China and chose South Korea. Kang halmoni wanted to be compensated for the happiness of her childhood that she had lost because of her motherland and for her social status in China, which she had lost once again by returning to her motherland. 
